\title{
On the identity of Eragrostis dayanandanii (Poaceae) described from Tamil Nadu, India
}

\author{
C. P. Vivek四, G. V. S. Murthy and V. J. Nair \\ Botanical Survey of India, Southern Regional Centre, Coimbatore - 641003 (Tamil Nadu). \\ 凶Corresponding author:vvkcpoulose@gmail.com
}

\section{भारत के तमिलनाडु राज्य से वर्णित इराग्रोस्टिस दयानन्दनी (पोएसी) की पहचान}

\author{
सी. पी. विवेक, जी. वी. एस. मूर्ति एवं वी. जे. नायर
}

\section{सारांश}

इराग्रोस्टिस दयानन्दनी रविचंद्रन एवं अन्य को इराग्रोस्टिस गंगेटिका (रॉक्स) स्ट्यूड के पर्याय के रूप में लिया गया है। इस पौधे के गुणों को सारणी में तथा इसके स्पाइकलेट, लेम्मास एवं केरियोप्सेस के छायाचित्र को दर्शाया गया है। इसके अतिरिक्त, भारत में पाये जाने वाली जाति इराग्रोस्टिस के पेलिया के कील्स पर पाये जाने वाले बालों के बारे में भी प्रकाश डाला गया है।

\section{ABSTRACT}

The name Eragrostis dayanandanii Ravichandran \& al. is reduced as synonym under Eragrostis gangetica (Roxb.) Steud. The characters of the species are tabulated and provided images of spikelets, lemmas and caryopses. Also discussed about the types of hairs on keels of palea found in Indian Eragrostis.

Keywords: Eragrostis dayanandanii, Poaceae, identity problem.

Eragrostis dayanandanii Ravichandran \& al. is a new species described from Tamil Nadu, India (Ravichandran \& al., 1996). These authors compared the species with $E$. malayana Stapf (E. montana Balansa) which has not been reported so far from India. The diagnostic characters of E. malayana include open to contracted and $3-10 \mathrm{~mm}$ long panicle; 1.5 - $2 \mathrm{~mm}$ broad spikelets; straight rachilla; broadly ovate lemmas; persistent and eciliate paleas; 3 stamens; and $0.4-0.5 \mathrm{~mm}$ long slightly laterally compressed caryopses. According to the authors, E. malayana is the allied species for $E$. dayanandanii and different from it mainly by having $6-10 \mathrm{~mm}$ long spikelets, prominently zigzag rachilla, equal length of lemmas and paleas and not laterally compressed caryopses. The present authors thoroughly studied the holotype of $E$. dayanandanii (Azhakanandan \& al., 235) deposited in $\mathrm{MH}$ and similar other specimens collected from the type locality and compared its characters with various Eragrostis species including E. gangetica (Roxb.) Steud., a species widely distributed in tropical Asia including India and also Africa. In this study it was found that the characters emphasized by the authors to differentiate $E$. dayanandanii from E. malayana match very well with those of $E$. gangetica about which nothing has been mentioned in the publication. Furthermore, a comparative study was carried out between E. dayanandanii and E. gangetica (table 1). Microscope images of the spikelets and caryopses of both the species are also given in fig. $\mathbf{1}$. Since the authors 


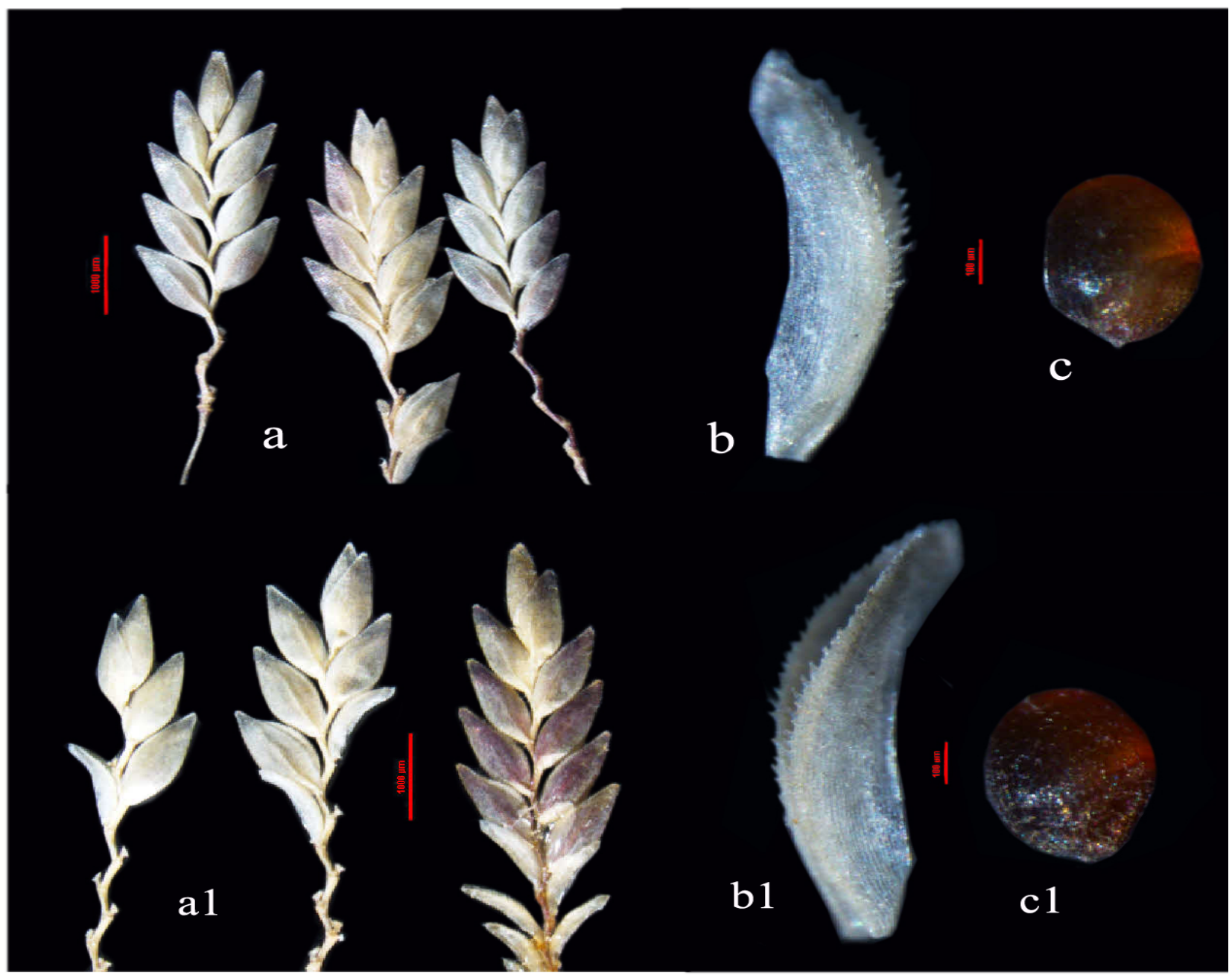

Fig -1: Eragrostis dayanandanii Ravichandran \& al. (a - c); E. gangetica (Roxb.) Steud.(a1 - c1) : a \& a1. Spikelets; b \& b1. Paleas; c \& c1. Caryopses.

Table -1: Salient characters of Eragrostis dayanandanii Ravichandran \& al. and E. gangetica (Roxb.) Steud.

\begin{tabular}{|c|c|c|}
\hline & E. dayanandanii (based on the study of holotype) & E. gangetica \\
\hline Culms & Annual, $10-15 \mathrm{~cm}$ high & Annual, $15-60 \mathrm{~cm}$ high \\
\hline Leaves & $\begin{array}{l}4-15 \times 0.2-0.5 \mathrm{~cm} \text {, ciliate with long hairs along basal } \\
\text { margins }\end{array}$ & $3-15$ x c. $0.4 \mathrm{~cm}$ long, margins villous hairy at base \\
\hline Ligules & Membranous with fringe of hairs & Membranous with fringe of hairs \\
\hline Panicle & Effuse, $4-10 \mathrm{~cm}$ long, alternate & Effuse, $4-10 \mathrm{~cm}$ long, alternate \\
\hline Spikelets & $6-10 \mathrm{~cm} \mathrm{x} 1-1.5 \mathrm{~mm}$, oblong to lanceolate & $3-10 \mathrm{~cm} \mathrm{x} 1-1.5 \mathrm{~mm}$, oblong to lanceolate \\
\hline Rachilla & Zigzag, partly persistent & Zigzag, partly persistent \\
\hline Florets & 6 - 36, disarticulating from below upwards & 6 - 35, disarticulating from below upwards \\
\hline Lemma & Deciduous, acute, purple tinged & Deciduous, acute, purple tinged \\
\hline Palea & c. $1 \mathrm{~mm}$ long, subpersistent, scaberulous along keels & c. $0.9 \mathrm{~mm}$ long, subpersistent, scaberulous along keels \\
\hline Stamens & 2; anthers c. $0.2 \mathrm{~mm}$ long, purplish & 2; anthers c. $0.2 \mathrm{~mm}$ long, purplish \\
\hline Caryopsis & c. $0.5 \times 0.2 \mathrm{~mm}$, ellipsoid to ovoid & c. $0.5 \times 0.2 \mathrm{~mm}$, ellipsoid to ovoid \\
\hline
\end{tabular}


mentioned the palea keels of E. dayanadanii as "shortly ciliate", this species has been placed in different websites under the category of Eragrostis with ciliate palea keels. However, the present study could prove that the "shortly ciliate" palea keels so mentioned in the protologue of $E$. dayanadanii is a character well referable to the "scaberulous" nature of the palea keels of E. gangetica and other species of Eragrostis having this character. This situation needs a discussion on the classification of Eragrostis based on the differences in the types of hairs along the keels of palea.

Species of Eragrostis in India can be categorized into 3 main groups based on the differences in the comparative length of the hairs along the keels of palea. In many species the keels are ciliate with the cilia either very long with or without bulbous bases as in E. amabilis (L) Wight \& Arn., E. ciliaris (L.) R. Br., E. ciliata (Roxb.) Nees etc., or medium sized and without any bulbous base as in $E$. deccanensis Bor, E. jainii Vivek, G.V.S. Murthy \& V.J. Nair etc. In the second group the hairs are minute in nature and this condition is usually termed as scabrous or scaberulous (E. gangetica, E. nutans (Retz.) Nees ex Wight \& Arn., E. unioloides (Retz.) Nees ex Steud. etc.), or ciliolate (E. zeylanica, E. cumingii etc.). In the third group as in E. japonica ((Thunb.) Trin. the keels of palea are smooth with the absence of hairs. E. dayanandanii falls within the second group of species which have keels of palea scaberulous. The comparative table given below shows that $E$. dayanandanii is in no way different from E. gangetica and as such has been reduced as a new synonym of the latter species.

Notes: Eragrostis gangetica, can be distinguished from all other species of the genus by the presence of membranous ligule with ciliate rim, open, effuse panicles, lanceolate to elliptic spikelets with florets disarticulating from below upwards, slender rachilla visible between florets, deciduous lemmas, persistent to subpersistent paleas with scaberulous keels, 2 small and purplish anthers and ellipsoid to ovoid caryopses.

The nomenclature of the species is summarized below Eragrostis gangetica (Roxb.) Steud., Syn. Pl. Glumac. 1: 266. 1854. Poa gangetica Roxb., Fl. Ind. 1: 341. 1820. TYPE: India, banks of Ganges, Roxburgh s.n. (holo BM). Eragrostis stenophylla Hochst. ex Miq., Verh. Konink.Nederl. Inst. 3, 4: 39. 1851, pro parte. TYPE: India, Mangalore, Hohenacker, R.F. 664 (holo BM: BM000959505). E. dayanandanii Ravichandran et al. in Kew Bull. 51: 155-157. 1996, syn. nov. TYPE: India, Tamil Nadu, Chengalpattu district, 24.01.1992, Azhakanandan, Krishnan, Ravichandran \& Samson 235 (holo MH; iso K, Madras Christian College Herbarium, Chennai).

\section{ACKNOWLEDGEMENTS}

Authors are thankful to the Ministry of Environment and Forests for financial support under their All India Coordinated Project in Taxonomy (AICOPTAX). Thanks are also due to Dr. Paramjit Singh, Director, Botanical Survey of India, Kolkata for his encouragement and facilities.

\section{REFERENCES}

RAVICHANDRAN, P., S. KRISHNAN, N.P. SAMSON, V.R. SUBBIAH, K. AZHAKANANDAM AND D. NARASIM-

HAN. 1996. Eragrostis dayanandanii - A new grass from Tamil Nadu, India. Kew Bull. 51(1): 155-157. 